\title{
The impact of land cover generated by a dynamic vegetation model on climate over east Asia in present and possible future climate
}

\author{
M.-H. Cho' ${ }^{1}$, K.-O. Boo ${ }^{2}$, G. M. Martin ${ }^{3}$, J. Lee ${ }^{2}$, and G.-H. Lim ${ }^{1}$ \\ ${ }^{1}$ School of Earth and Environmental Sciences, Seoul National University, Seoul, Republic of Korea \\ ${ }^{2}$ National Institute of Meteorological Research, Korea Meteorological Administration, Jeju, \\ Republic of Korea \\ ${ }^{3}$ Met Office Hadley Centre, FitzRoy Road, Exeter, UK \\ Correspondence to: M.-H. Cho (mhjo77@snu.ac.kr)
}

Received: 14 August 2014 - Published in Earth Syst. Dynam. Discuss.: 17 October 2014

Revised: 9 March 2015 - Accepted: 11 March 2015 - Published: 7 April 2015

\begin{abstract}
This study investigates the impacts of land cover change, as simulated by a dynamic vegetation model, on the summertime climatology over Asia. The climate model used in this study has systematic biases of underestimated rainfall around Korea and overestimation over the South China Sea. When coupled to a dynamic vegetation model, the resulting change in land cover is accompanied by an additional direct radiative effect over dust-producing regions. Both the change in land surface conditions directly and the effect of increased bare-soil fraction on dust loading affect the climate in the region and are examined separately in this study. The direct radiative effect of the additional dust contributes to increasing the rainfall biases, while the land surface physical processes are related to local temperature biases such as warm biases over North China. In time slice runs for future climate, as the dust loading changes, anomalous anticyclonic flows are simulated over South China Sea, resulting in reduced rainfall over the South China Sea and more rainfall near Korea and south China. In contrast with the rainfall changes, the influence of land cover change and the associated dust radiative effects are very small for a future projection of temperature, which is dominated by atmospheric $\mathrm{CO}_{2}$ increase. The results in this study suggest that the land cover simulated by a dynamic vegetation model can affect, and be affected by, model systematic biases on regional scales over dust emission source regions such as Asia. In particular, the analysis of the radiative effects of dust changes associated with land cover change is important in order to understand future changes in regional precipitation in global warming.
\end{abstract}

1

Bordered by the Tibetan Plateau to the west, the Eurasian land mass to the northwest, and the vast Pacific Ocean to the south and east, east Asia has experienced one of the most pronounced monsoon climates of the globe for centuries (Lau and $\mathrm{Li}, 1984$ ). Land surface properties are important because of their known impact on the east Asian monsoon circulation (Kang and Hong, 2008; Lee et al., 2011) and on the Indian monsoon (Douglas et al., 2006; Lee et al., 2009; Batlle Bayer et al., 2012; Martin and Levine, 2012). Lee et al. (2011) proposed that a replacement of vegetation with bare soil would cause an associated decrease in latent heat during the summer, which could weaken east Asian monsoon circulation. This decrease in latent heat flux over land could weaken the east Asian monsoon via a positive feedback between the latent heat flux contrast and rainfall. Yamashima et al. (2011) carried out a similar study over the Indian subcontinent and southeastern China. Land surface property changes from forest to cultivated land have resulted in a decrease in the monsoon rainfall and provoked an associated weakening of the Asian summer monsoon circulation. Moreover, there are a few studies investigating the influence of land cover change that have demonstrated a significant impact on the east Asian 
monsoon (Kang et al., 2005), but they usually used satellitebased (Suh and Lee, 2004; Kang and Hong, 2008) and idealized land cover change (Lee et al., 2011).

Although earth system models with dynamic vegetation schemes allow the representation of the carbon cycle feedbacks on climate, the land cover distribution could also be influenced by, and indeed influence, model systematic biases (Martin and Levine, 2012, hereafter ML12). Land surface property changes have effects on the atmosphere through physical processes (such as changes in surface roughness, albedo and evapotranspiration) and can induce additional indirect impacts when coupled with aerosol processes as well. For example, changes in surface emissions of mineral dust that are caused by changes in bare-soil fraction will have a radiative effect on the atmosphere. Additional dust loading of the atmosphere resulting from land cover change in an earth system model could, therefore, add to the model uncertainty via feedbacks with model systematic biases such as a lack of rainfall over dust-producing regions. Dust affects both shortwave and longwave radiative fluxes, and the effects of mineral dust on the radiation budget are important due to the widespread distribution and large optical depth of mineral dust (Sokolik and Toon, 1996). A study by Yoshioka et al. (2007) suggests that the direct radiative forcing of dust can explain up to $30 \%$ of the observed precipitation reduction in the Sahel in 30-year simulations. Dust is removed from the atmosphere by both dry- and wet-deposition processes, providing a source of iron to phytoplankton and thus potentially affecting the carbon cycle (Collins et al., 2011). Since northeast Asia is one of the major dust emission source regions, land surface property changes over this source region need to be studied. Aerosol, as one of the fundamental atmospheric constituents, has an important impact on the climate system. Ramanathan et al. (2005) showed that global dimming causes a long-term (multi-decadal) weakening of the south Asian monsoon by reducing the meridional surface temperature gradient between the Asian land mass and the Indian Ocean. Aerosol affects precipitation events through cloud physics processes in China (Qian et al., 2009), while dust can also contribute to Asian monsoon rainfall anomalies by heating the upper troposphere (Lau et al., 2006, Lau and Kim, 2006). Therefore, aerosol impacts due to land cover changes may be important in regional climate over east Asia.

ML12 investigated the impacts on climate of land cover changes, and associated dust effects, that resulted from model systematic biases. Their results reflect that over dustproducing regions, land cover change simulated by a dynamic global vegetation model (DGVM) can affect both the present-day simulation and the future response as well. According to Hurrell et al. (2009) and McCarthy et al. (2012), since model systematic biases affect climate model sensitivity, we need to study processes related to systematic biases in order to understand future climate projections. Motivated by ML12, this study extends ML12 by applying their results to east Asia. The aims of this study are as follows: first, to investigate the physical influence of changes in land cover conditions and associated changes in aerosol loading on the rainfall and surface temperature over east Asia, and second, to provide insight into the possibly conflicting contributions to uncertainty in climate projections for the region that come from the inclusion of dynamic vegetation in a climate model (which ought to be beneficial) and its interaction with existing precipitation biases (which is detrimental).

The present paper is organized as follows. Section 2 briefly describes the global circulation model used in this study, the experimental design and the data. The results of the study are given in Sect. 3. The impact of land cover distribution and the radiative effect of dust under the present and possible futures climate are all provided in this section. A summary and discussion are given in Sect. 4.

\section{Model experimental design and data}

In this study, we used the same data sets as used in ML12, and we follow a similar methodology for the analysis, with additional investigation of particular aspects concerning the east Asian region. The experiments were produced using the Hadley Centre Global Environmental Model version 2 (HadGEM2) model family that was developed by the UK Met Office (The HadGEM2 Development Team, 2011). The horizontal grid interval was $1.25^{\circ} \times 1.875^{\circ}$ in the latitudelongitude directions, and 38 vertical layers were used with the top of atmosphere over $39 \mathrm{~km}$ in height. The land surface scheme in the HadGEM2 family is a tiled version of the Met Office Surface Exchange Scheme (MOSES) version 2, which represents heterogeneous surface properties (Cox et al., 1999; Essery and Clark, 2003). A grid box represents a mixture of five vegetation or plant functional types (PFTs), which include broadleaf trees, needleleaf trees, temperate $\mathrm{C}_{3}$ grass, tropical $\mathrm{C}_{4}$ grass and shrubs, and four non-vegetated surface types, which include urban, inland water, bare soil and ice. Surface fluxes and temperatures are calculated separately for each surface type and are aggregated according to each tile's fractional coverage before being passed to the atmospheric model (Lawrence and Slingo, 2004).

The experiment configuration used by ML12 is as follows. For the present-day (1980-2005) runs, the HadGEM2 atmosphere-only model was forced with observed sea surface temperatures (SSTs) and sea ice. The experimental design and forcing data sets are as specified by the Fifth Coupled Model Intercomparison Project (CMIP5; Taylor et al., 2012) and are detailed in Taylor et al. (2012). The land cover and vegetation types were prescribed by the International Geophysical Biophysical Programme (IGBP; Loveland et al., 2000) with a prescribed seasonally varying leaf area index (LAI) based on Moderate Resolution Imaging Spectroradiometer (MODIS) Terra Collection 5 monthly LAI data sets. Historical land use change information based on CMIP5, provided to CMIP5 by the Land Use Harmonization team 
(Hurtt et al., 2011), were applied by Baek et al. (2013) to the IGBP land cover data in order to prescribe time-varying land cover fields for HadGEM2-A. This is referred to as the "A" experiment.

For the future time slice experiments, the atmosphere component is forced with $\mathrm{CO}_{2}$ and trace gases for the year 2100, based on the Representative Concentration Pathway (RCP) 8.5 scenario of the CMIP5 (Taylor et al., 2012). The SSTs were obtained by applying the difference between 30-year mean SSTs centred around 2100 (from the HadGEM2 Earth System (HadGEM2-ES) RCP8.5 scenario coupled model run) and 30-year mean SSTs centred around 1990 (from the HadGEM2-ES historical run) to the present-day monthly varying observed SSTs from 1980 to 2005. The projected future land use changes for the period 2080-2110 based on CMIP5 RCP8.5 scenarios were applied in order to prescribe time-varying land cover fields (Hurtt et al., 2011) for the HadGEM2-A time slice experiment. This is referred to as the "Ats" experiment.

In addition to the "A" and "Ats" experiments, alternative representations of global vegetation cover from a DGVM were used as the land cover component for further HadGEM2-A experiments under present-day and future climates. In these experiments, the only change made is that the monthly mean land cover information from the HadGEM2ES historical and RCP8.5 runs is used in HadGEM2-A in place of the standard land cover distribution as described above. The HadGEM2-ES configuration uses the Top-down Representation of Interactive Foliage and Flora Including Dynamics (TRIFFID) dynamic vegetation model (Cox, 2001) to simulate the land cover changes. Therefore, in these additional experiments, the variations in land cover with time during these periods in HadGEM2-ES are experienced by HadGEM2-A, but there are no interactive terrestrial carbon cycle and no feedbacks on the land cover. Variations in land cover from the years 1980 to 2005 of HadGEM2-ES are used in the present-day experiment of this type, referred to as "AE", while the variations in land cover from the years 2080 to 2110 of HadGEM2-ES are applied to the future time slice experiment denoted "AEts". Note that crops are not represented explicitly in HadGEM2-ES; crop and pasture are assumed to be a combination of $\mathrm{C}_{3}$ and $\mathrm{C}_{4}$ grass. Details of how land use changes relating to cropland are applied in HadGEM2-ES are given in Jones et al. (2011). This simplification could affect the sensitivity to land cover changes in east Asia in our experiments.

A mineral dust scheme (Woodward, 2011) is included in the HadGEM2 model family (HadGEM2 Development Team, 2011), which permits the simulation of changes in mineral dust concentration in response to changes in surface conditions as well as its interaction with model climate via radiative effects. According to ML12, the AE experiment shows a large increase in dust, which is generated as a result of the feedback between the interactive vegetation and the model's systematic rainfall biases in dust-producing regions.
Table 1. List of experiments.

\begin{tabular}{lll}
\hline Acronym & Description of the experiments & Time \\
\hline A & HadGEM2-A & \\
AE & HadGEM2-A with ES vegetation & Present \\
Anod & HadGEM2-A with no & 1980-2005 \\
& dust radiative effects & \\
AEnod & HadGEM2-A with ES vegetation & \\
& with no dust radiative effects & \\
Ats & HadGEM2-A time slice run & Future \\
AEts & HadGEM2-A with ES vegetation time slice run & 2080-2110 \\
AEnodts & HadGEM2-A with ES vegetation time slice & \\
& run with no dust radiative effects & \\
\hline
\end{tabular}

Dust is only emitted from the bare-soil fraction of a grid box and therefore is sensitive to changes to this fraction when the DGVM is used. In the model, the dust affects both shortwave and longwave radiative fluxes. The semi-direct effect is included implicitly with absorption by the dust feeding back into the atmospheric heating profiles and subsequently cloud distributions, but the dust is not microphysically active. To evaluate the radiative effects of the dust, an additional pair of experiments was carried out where the direct radiative effects of the dust were switched off. This reduces the dust to a passive tracer in the model with no feedback on the climate. These experiments have the suffix "nod" meaning "no dust radiative effects". Therefore, "Anod" means a HadGEM2A simulation with the standard land cover distribution in the present-day; "AEnod" means a HadGEM2-A presentday simulation with HadGEM2-ES land cover without the direct radiative effects of the dust; and "AEnodts" means a HadGEM2-A future time slice simulation with HadGEM2ES land cover without the direct radiative effects of dust. All of the experiments are listed in Table 1.

To compare model results in the present-day runs with observations we used the Global Precipitation Climatology Project (GPCP) precipitation (Alder et al., 2003; Huffman et al., 2009), the CPC Merged Analysis of Precipitation (CMAP; Xie and Arkin, 1997) and the Climatic Research Unit (CRU) mean surface air temperature (Harris et al., 2013). In this study, summer represents the period from June to August.

\section{Modelling results}

\subsection{Present day}

\subsubsection{Impact of ES land cover on average temperature and precipitations}

First we examine summer precipitation over east Asia. Figure 1a shows the climatological summertime precipitation distribution of the east Asian summer monsoon. The summer monsoon rainy season evolves with the rainband development covering south China, Korea, Japan and the adjacent seas. The formation of frontal systems is associated with 
(a) GPCP rainfall and wind

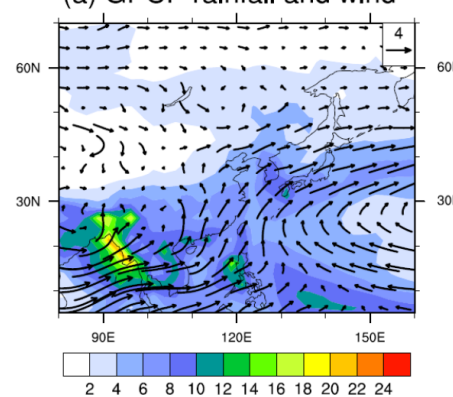

(b) GPCP - CMAP

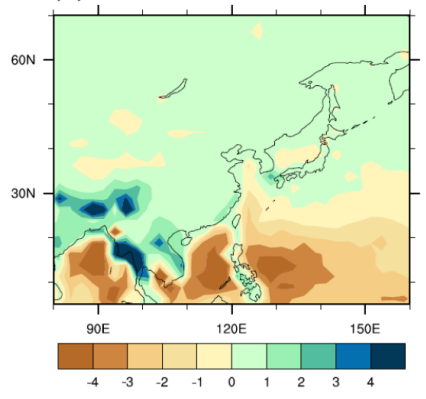

Figure 1. The 1982-2005 JJA (a) climatology of the Global Precipitation Climatology Project (GPCP) precipitation $\left(\mathrm{mm} \mathrm{day}^{-1}\right.$, shading) and $850 \mathrm{hPa}$ winds $\left(\mathrm{m} \mathrm{s}^{-1}\right)$ and (b) precipitation difference between GPCP and the CPC Merged Analysis of Precipitation (CMAP).

the North Pacific subtropical high and southwesterlies over the South China Sea. The rainband region, in contrast with the equatorial region, has a small observational uncertainty (Fig. 1b). In Fig. 2, we analyse the North China (NC) region, $\left(35-50^{\circ} \mathrm{N}, 105-120^{\circ} \mathrm{E}\right)$, Korea (KR), $25-40^{\circ} \mathrm{N}, 120-135^{\circ} \mathrm{E}$ and south China (SC) region $\left(20-35^{\circ} \mathrm{N}, 105-120^{\circ} \mathrm{E}\right)$, which together represent a large contrast in land cover distribution over east Asia. Simulated precipitation compared with observation (GPCP precipitation) shows a systematic bias in Fig. 2. Precipitation is underestimated over the KR area and overestimated over SC. These spatial features remain in AE, although the underestimated rainfall over KR becomes larger in $\mathrm{AE}$ than $\mathrm{A}$.

Figure 3 represents summer surface air temperature bias in the model results compared with the CRU observation data. There is a warm bias greater than $1 \mathrm{~K}$ in $\mathrm{NC}$ and $\mathrm{KR}$ but only a small bias in SC (Fig. 3a). The warm bias over KR is slightly smaller in AE compared to A (Fig. 3c, d). In order to shed light on the bias changes on the regional scale, the land cover difference between $\mathrm{AE}$ and $\mathrm{A}$ is examined (Fig. 4). Among the five vegetation and bare-soil surface types over east Asia, the largest changes are in broadleaf, $\mathrm{C}_{3}$ grass and bare-soil types. Over North China, the increase in the baresoil fraction is large. This unrealistically high bare-soil fraction has an impact on high dust emission over this region because dust is only emitted from the bare-soil fraction of a grid box in this model. In contrast, the south China region is covered by larger broadleaf fraction (Fig. 4) in the AE compared with A, replacing bare soil, shrub and needleleaf tree. To the north of $50^{\circ} \mathrm{N}$, the increase into shrub fraction is distinct (also seen in Fig. 4 of ML12).

ML12 showed that bare-soil area expansion from the changes in the vegetation distribution between $\mathrm{AE}$ and $\mathrm{A}$ generates additional dust, resulting in a substantial direct radiative impact on the Indian monsoon rainfall. They suggest a separate analysis for the dust radiative feedback resulting from land cover change from the analysis of the effects of the change in surface conditions. Accordingly, we examine experiments Anod and AEnod (see Table 1).

In Fig. 2, a marked precipitation underestimation over KR is shown compared with observations, particularly when the ES land cover is used. The dry-bias amplitudes in summer become larger in AE compared with A (Fig. 2). To estimate the radiative effect of dust on rainfall when the HadGEM2ES land cover distribution was used, AE was compared with AEnod. The dry-bias amplitude of AE decreases in AEnod (Fig. 2c and f) but is still slightly larger than in A. Thus the radiative effect of dust reinforces the dry bias in the KR region (compare Fig. 2b and e with Fig. 2c and f). This is consistent with the results of ML12 for the south Asian region. ML12 showed significant effects of the change in dust loading on the clear-sky radiative fluxes across south and east Asia (their Fig. 7) and commented on the impacts on surface temperatures, which tend to reduce precipitation through cooling of the daytime maxima.

To examine the dust radiative effect and land cover change effect in detail, the dry bias in summer over KR in Fig. 2 is considered using Fig. 5. The pattern of changes between "AE" and "A" in Fig. 5a is similar to the "AE-AEnod" changes (Fig. 5c) rather than those of "AEnod-Anod" (Fig. 5b). This suggests that precipitation over east Asia is more sensitive to the radiative effects of dust associated with land cover changes than to the land cover change alone.

In Fig. 6 we make a similar comparison for surface air temperature changes. We find that the dust radiative effect on surface air temperature is associated with a small widespread cooling (Fig. 6c), whereas the surface process effects of the land cover change are associated with a more substantial warming and cooling pattern across the region, as shown in the AEnod-Anod (Fig. 6b) and AE-A (Fig. 6a) differences. Over northeastern Eurasia, the increase in shrub fraction replacing broadleaf and needleleaf trees shows a distinct cooling of surface air temperature induced by an increase of surface albedo.

\subsubsection{Impact of changes in land cover with no dust radiative feedback}

To understand more clearly the impacts of the changes in the vegetation distribution in Fig. $6 a$ and $b$, we examined the climate response without the direct radiative effect of dust. The aforementioned increase in warm bias over NC AEnod-Anod (Fig. 6b) is considered. Over NC, as the baresoil fraction is larger in AE than A (Figs. 4f; 7ab), the roughness length reduces, while soil evaporation and canopy evaporation decrease. Reduced roughness length induces a decrease in sensible and latent heat fluxes from the surface to the atmosphere (Fig. 7c, d, f). The decrease in latent heat flux is associated with reduced cloud amount (Fig. 7e), as well as being favourable for surface warming. As a result, surface air temperature rises over NC (Fig. 7h). The reduced latent heat flux is particularly evident in the canopy evaporation in the 
(a) A

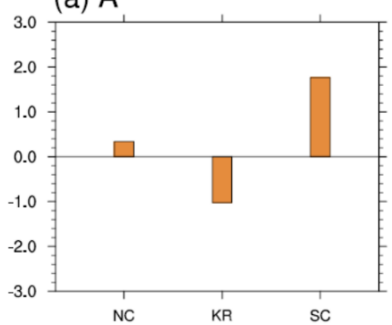

(d) $\mathrm{A}$

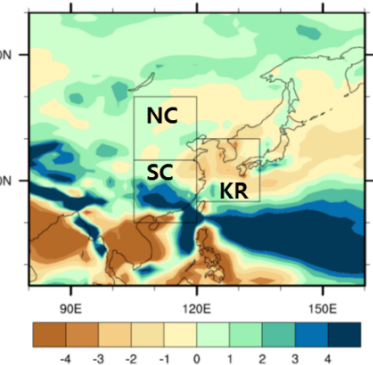

(b) $\mathrm{AE}$

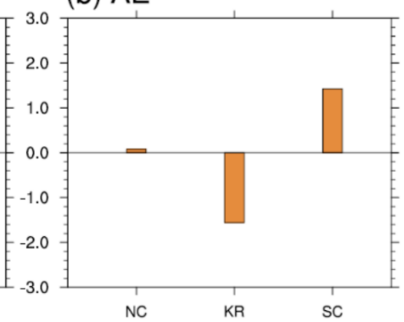

(e) $\mathrm{AE}$

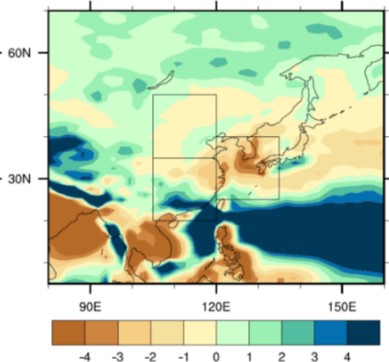

(c) AEnod

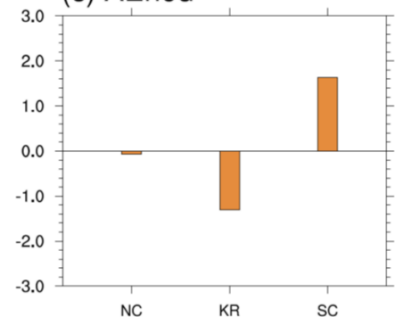

(f) AEnod

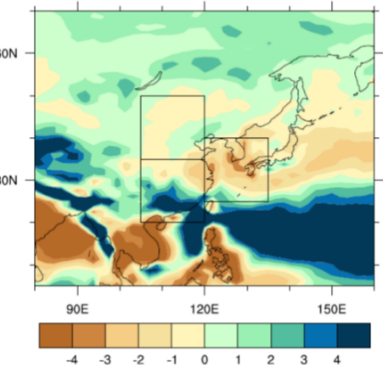

Figure 2. Area-averaged JJA precipitation bias ( $\mathrm{mm} \mathrm{day}^{-1}$ ) compared to the Global Precipitation Climatology Project (GPCP) observation: $(\mathbf{a}, \mathbf{b}$ and $\mathbf{c})$ show regional mean biases over the regions shown in (d, e and $\mathbf{f})$. $\mathrm{NC}$ region: $35-50^{\circ} \mathrm{N}, 105-120^{\circ} \mathrm{E} ; \mathrm{KR}: 25-40^{\circ} \mathrm{N}, 120-135^{\circ} \mathrm{E}$; SC region: $20-35^{\circ} \mathrm{N}, 105-120^{\circ} \mathrm{E}$.

(a) A

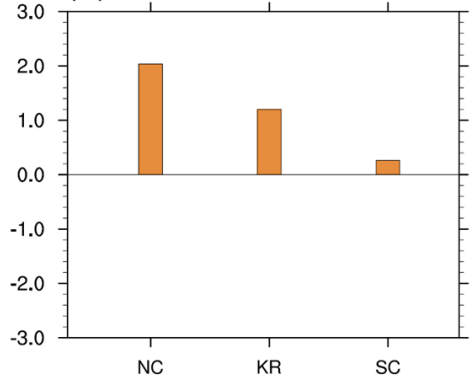

(c) $\mathrm{A}$

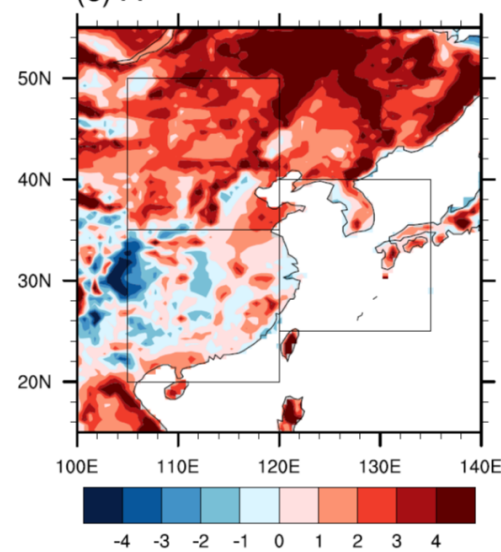

$\begin{array}{llllllllll}-4 & -3 & -2 & -1 & 0 & 1 & 2 & 3 & 4\end{array}$ (b) $\mathrm{AE}$

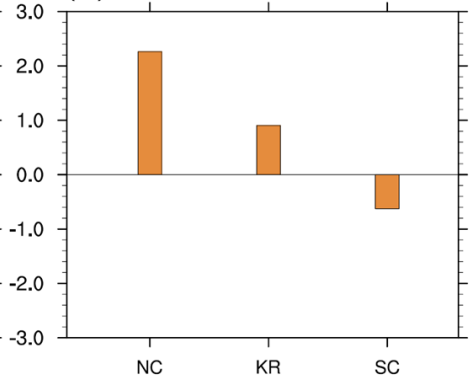

(d) $\mathrm{AE}$

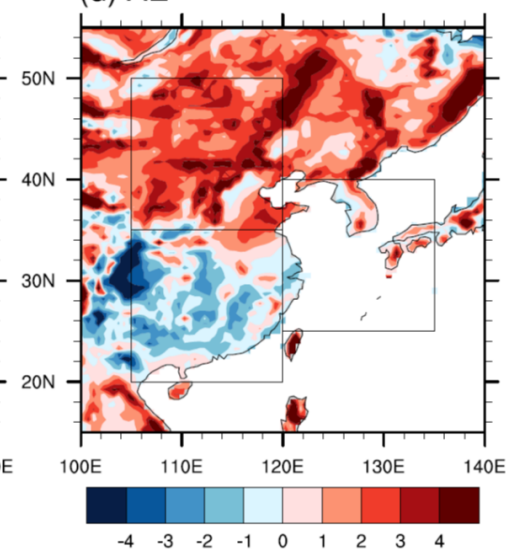

Figure 3. As Fig. 1 but for JJA surface air temperature biases (K) compared to the Climatic Research Unit (CRU) climatology. 
(a) Broadleaf tree

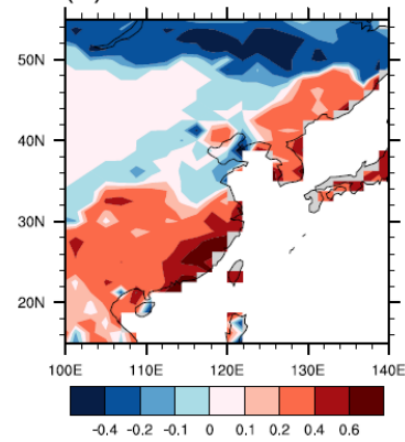

(d) C4 grass

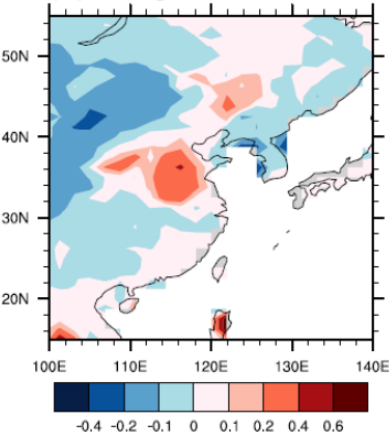

(b) Needleleaf tree

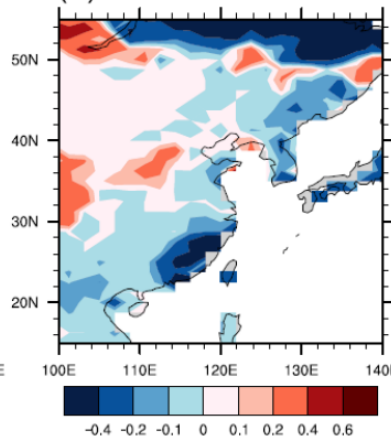

(e) Shrub (c) C3 grass
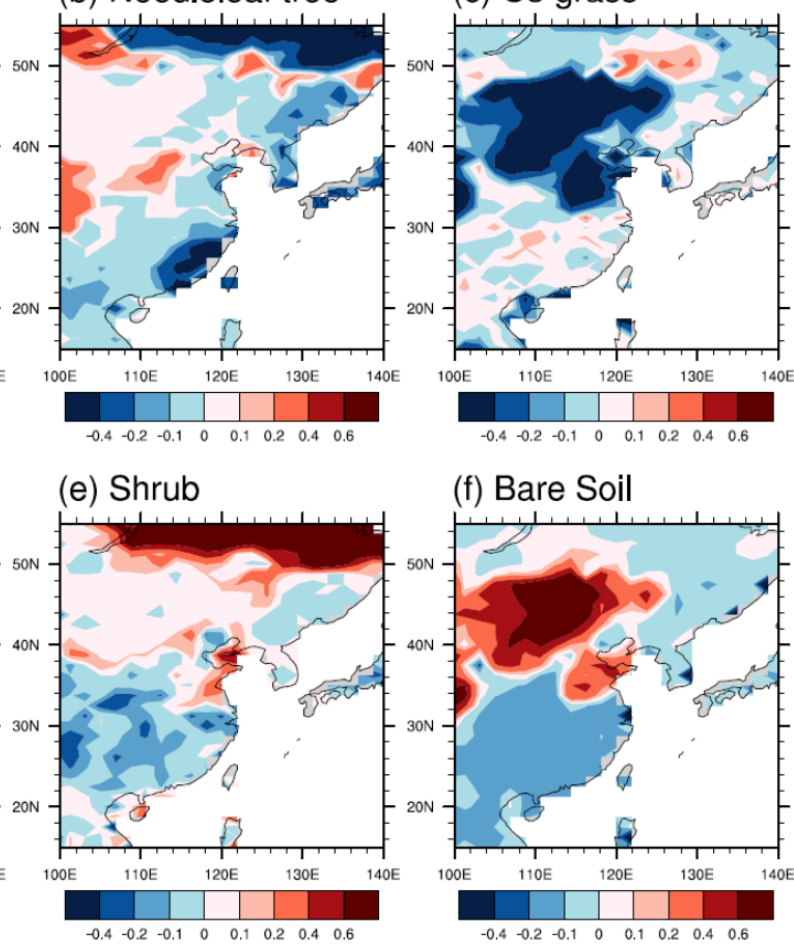

(f) Bare Soil

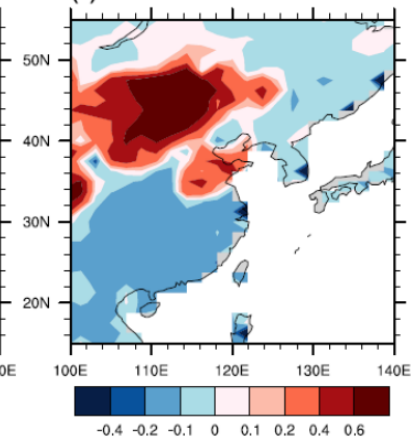

Figure 4. Differences in present-day (1980-2005) fractions of land cover type between HadGEM2-ES and HadGEM2-AO (and HadGEM2A) over east Asia.
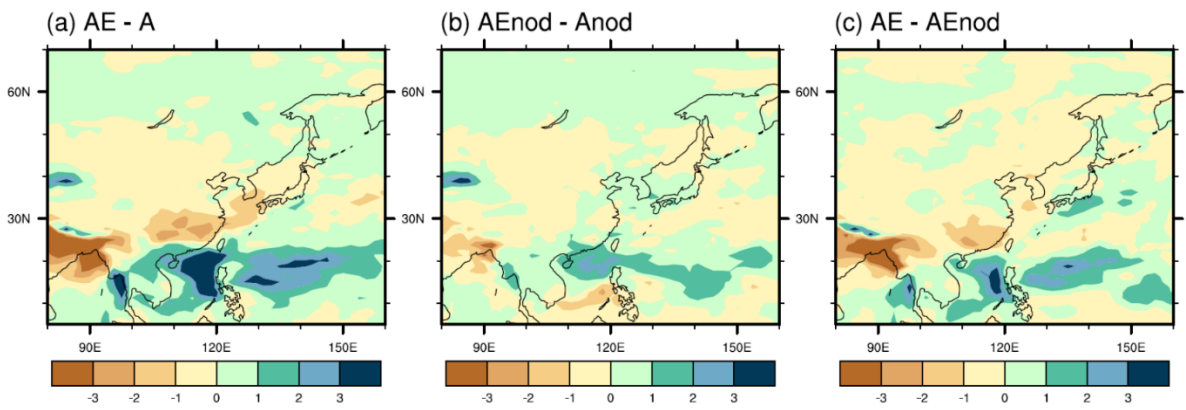

Figure 5. Precipitation differences $\left(\mathrm{mm} \mathrm{day}^{-1}\right.$ ) in JJA for (a) AE-A (b) AEnod-Anod and (c) AE-AEnod.

$\mathrm{NC}$ region, although there is also reduced soil evaporation during the summer (not shown).

Similarly, surface cooling over SC and KR is considered in summer. Broadleaf tree fraction expansion (Fig. 7b) increases the roughness length (Fig. 7f) and latent heat flux (Fig. 7c), driving surface cooling. While the NC region, where baresoil fraction is increased, showed a decrease in evaporation from $\mathrm{A}$ to $\mathrm{AE}$, in the $\mathrm{KR}$ and $\mathrm{SC}$ regions where broadleaf tree fraction is increased, there is increased soil and canopy evaporation from A to AE. These results are consistent with the suggestion by Lee et al. (2011) that a vegetation replacement with bare soil would cause an associated decrease in latent heat during the summer. In summary, for the present climate, the land cover effect (bare-soil fraction changes in
Fig. 7a) is related to surface air temperature changes in summer (Fig. 7h). As bare-soil fraction expands (shrinks) the temperature rises (drops).

As regards precipitation, Fig. 6 shows only very small changes in precipitation over land in AEnod-Anod (Fig. 6b), and Fig. 10a also shows only small changes in the circulation between these experiments. Thus, the model's direct sensitivity of precipitation to changes in land surface conditions seems to be low compared with the sensitivity to the dust changes that result from them. Although this conclusion is similar to that for India in ML12, the remote influence of changes in springtime Eurasian snow cover associated with the change in vegetation was highlighted for south Asia in 

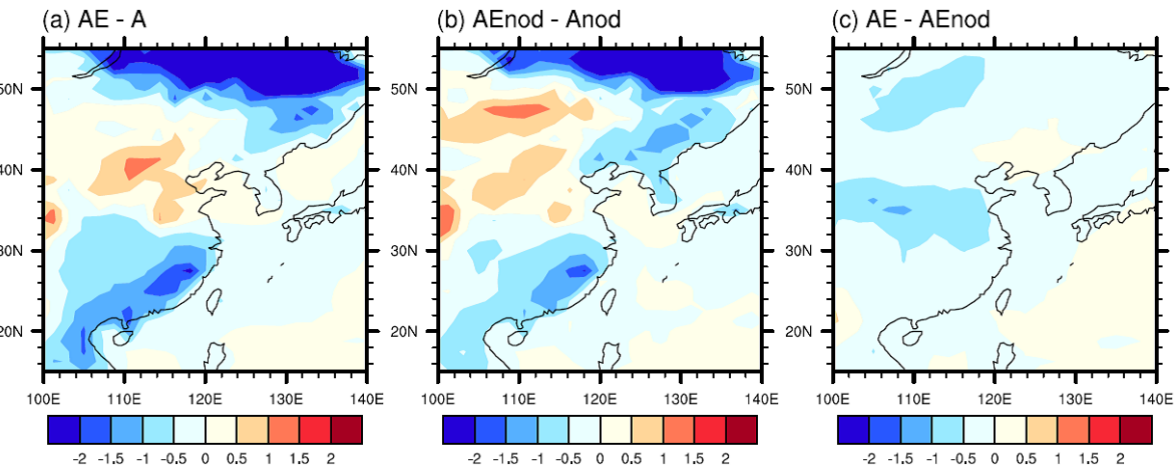

Figure 6. Surface air temperature differences (K) in JJA for (a) AE-A, (b) AEnod-Anod and (c) AE-AEnod.
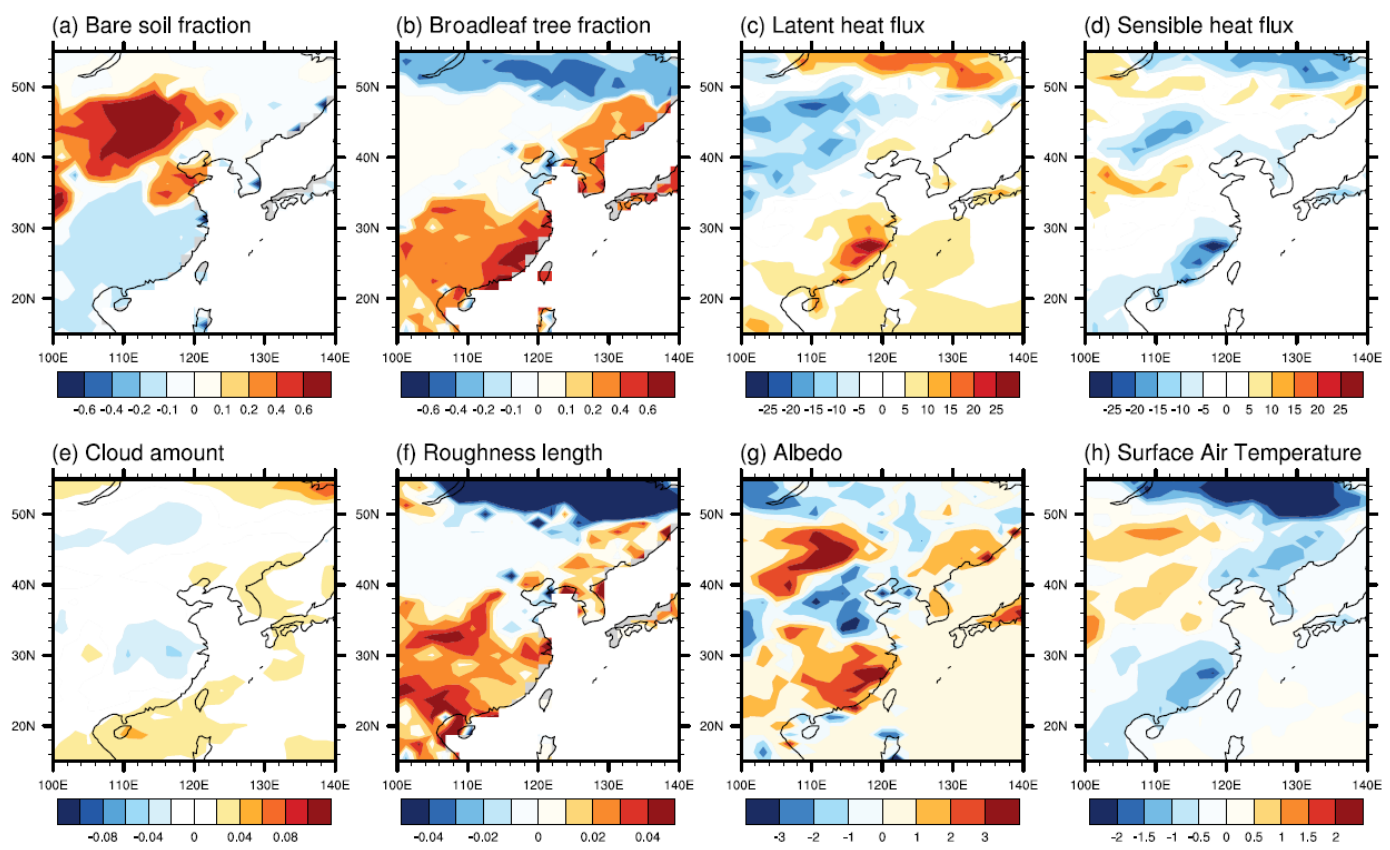

Figure 7. AEnod-Anod in JJA showing the applied fractional land cover changes and their impact in (a) bare-soil fraction, (b) broadleaf tree fraction, (c) latent heat flux $\left(\mathrm{W} \mathrm{m}^{-2}\right)$, (d) sensible heat flux $\left(\mathrm{W} \mathrm{m}^{-2}\right)$, (e) cloud amount (fraction), (f) roughness length (m), (g) albedo $(\%)$ and (h) surface air temperature (K).

that study, whereas for the east Asian region we have shown a more local influence of changes in surface conditions.

\subsubsection{Impact of dust radiative feedback}

We now consider the direct radiative effect of dust resulting from the changes in the vegetation distribution (AEnod-Anod and AE-AEnod of Fig. 8). Concerning the regional climate response, the dust direct radiative effects (Fig. 8b) lead to an anomalous northeasterly coastal flow counteracting the summertime climatological monsoonal circulation associated with the western North Pacific high, known to be important in the east Asian summer monsoon rainfall (Lee et al., 2006 and Fig. 8c). The sea level pressure and wind anomalies in AE-AEnod are stronger than those of AEnod-Anod (Fig. 8a and b), illustrating that the radiative effects of the dust have a larger impact than the surface vegetation changes themselves.

The direct radiative effect of dust induces an anomalous cyclonic flow over the western North Pacific (KR region in Fig. 8b) that would tend to decrease rainfall over the east Asian continent. This is because dust reflects a considerable amount of shortwave radiation, as shown by the increase in upward shortwave radiation at the top of the atmosphere (TOA; Fig. 8f), with a resulting cooling of the land surface (Fig. 8d). The land surface cooling appears on the continental scale. This is somewhat different from the results in Miller and Tegen (1998), who mentioned that the reflected solar flux is offset by the absorption of upwelling longwave radiation, so that the net radiation entering the TOA is only weakly 

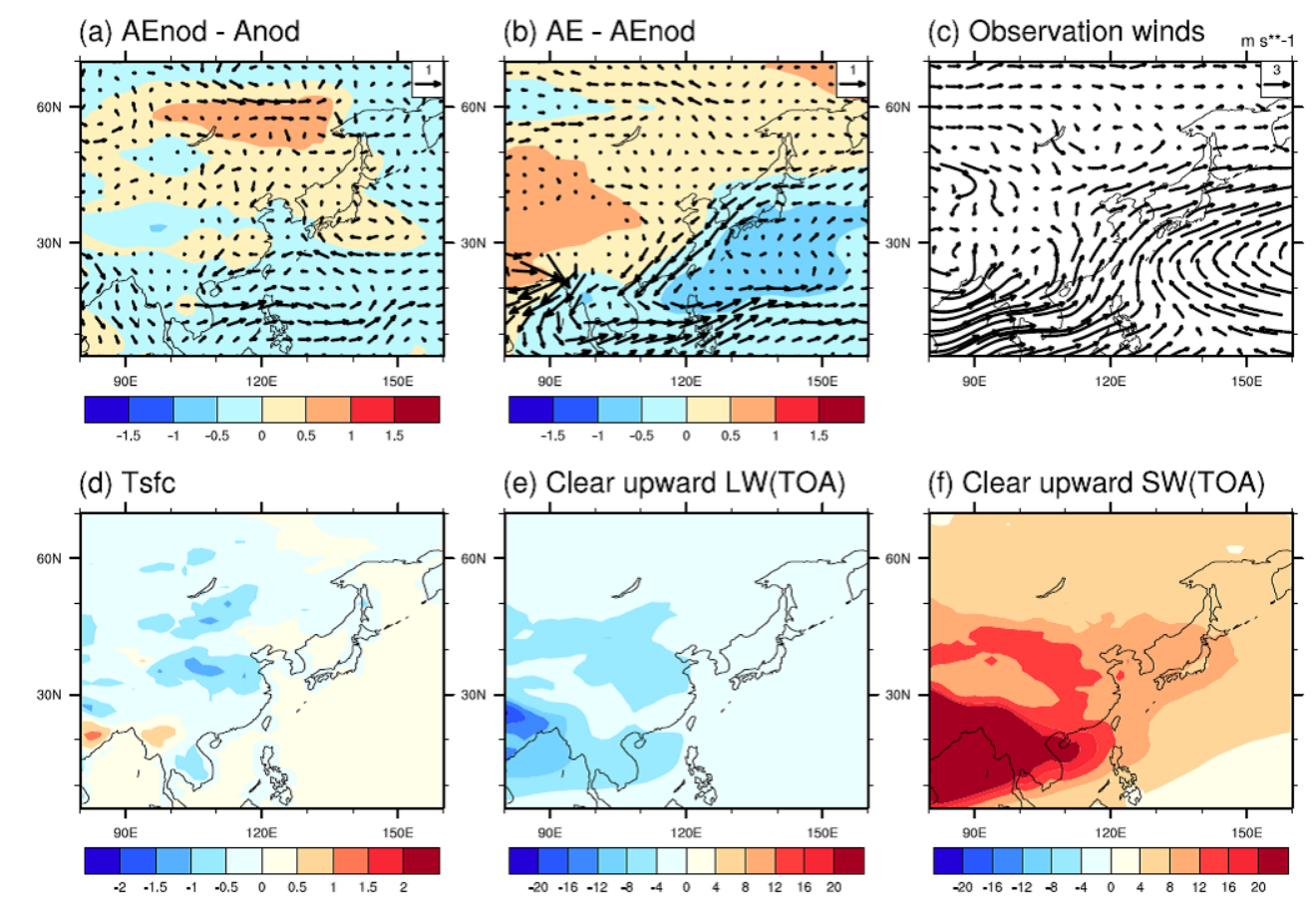

(e) Clear upward LW(TOA)

(f) Clear upward SW(TOA)

Figure 8. Changes in mean sea level pressure (hPa) and $850 \mathrm{hPa}$ winds $\left(\mathrm{m} \mathrm{s}^{-1}\right)$ in JJA for (a) AEnod-Anod and (b) AE-AEnod. (c) Climatology of $850 \mathrm{hPa}$ winds for the period 1982-2005 using ERA Interim; (d to f) show differences between AE and AEnod in JJA: (d) surface temperature $(\mathrm{K})$, (e) clear-sky upward longwave radiation $\left(\mathrm{W} \mathrm{m}^{-2}\right)$ and (f) clear-sky upward shortwave radiation $\left(\mathrm{W} \mathrm{m}^{-2}\right)$ at top of atmosphere, showing the impacts of the radiative effects from additional dust loading induced by the ES land cover.

perturbed by dust in comparison to the surface reduction. Although the upward longwave flux is reduced through the dust radiative effects (Fig. 8e), the reduction is smaller than the increase in reflected shortwave at the TOA. Differential heating between land and ocean is one of the fundamental driving mechanisms of the monsoon (Webster et al., 1998). The land-sea thermal contrast becomes weaker due to the direct radiative effect of dust and the pressure contrast weakens. Strong anomalous northeasterly flow along the coast (Fig. 8b), weakening the summer monsoon inflow, induces the dry bias over SC and KR (Fig. 5c). These results seem in line with the argument that dust-induced surface cooling is the dominant mechanism leading to a reduction in precipitation (Konaré et al., 2008; Yoshioka et al., 2007; Paeth and Feichter, 2005).

\subsection{Future experiments}

The effect of including a DGVM, particularly with the feedback on the dust loading, is expected to affect the simulation of future climate change. Changes in AEts relative to $\mathrm{AE}$ show increases in rainfall over $\mathrm{SC}, \mathrm{KR}$ and the western North Pacific (Fig. 9b). Compared with differences between Ats and A in Fig. 9a, differences between AEts and AE in Fig. 9b show a further reduction in rainfall over the South China Sea (SCS) to the south of $20^{\circ} \mathrm{N}$ accompanied by anticyclonic flow at $850 \mathrm{hPa}$. The discrepancy in future changes
Table 2. Impacts of climate change, land cover change and dust loading obtained by the difference between the experiments in this study.

\begin{tabular}{ll}
\hline Impact & Descriptions \\
\hline Climate change (Global warming) & Ats-A \\
Climate change + LCC + Dust & AEts-AE \\
Climate change + LCC & AEnodts-AEnod \\
Dust & (AEts-AE) - (AEnodts-AEnod) \\
LCC (ES land cover) & (AEnodts-AEnod) - (Ats-A) \\
\hline
\end{tabular}

in precipitation tends to be larger than that in temperature: Fig. $9 \mathrm{c}$ and $\mathrm{d}$ present similar warming patterns.

In order to examine the role of different vegetation distributions in global warming, with and without the dust feedbacks, we analyse future time slice experiments in a similar manner to ML12. To estimate individually the impact of land cover, feedback on the dust loading and climate change of global warming, we use the experiments described in Table 2. Note that "Dust" and "LCC" are "double differences", illustrating the impacts of the inclusion of the land cover changes, and the radiative effects of the dust changes that the land cover change induces, on the future-present differences.

According to Baek et al. (2013), the warming and rainfall increments from RCP8.5 are expected to be of the order of $6 \pm 1 \mathrm{~K}$ and $17 \%$ over east Asia. The temperature 


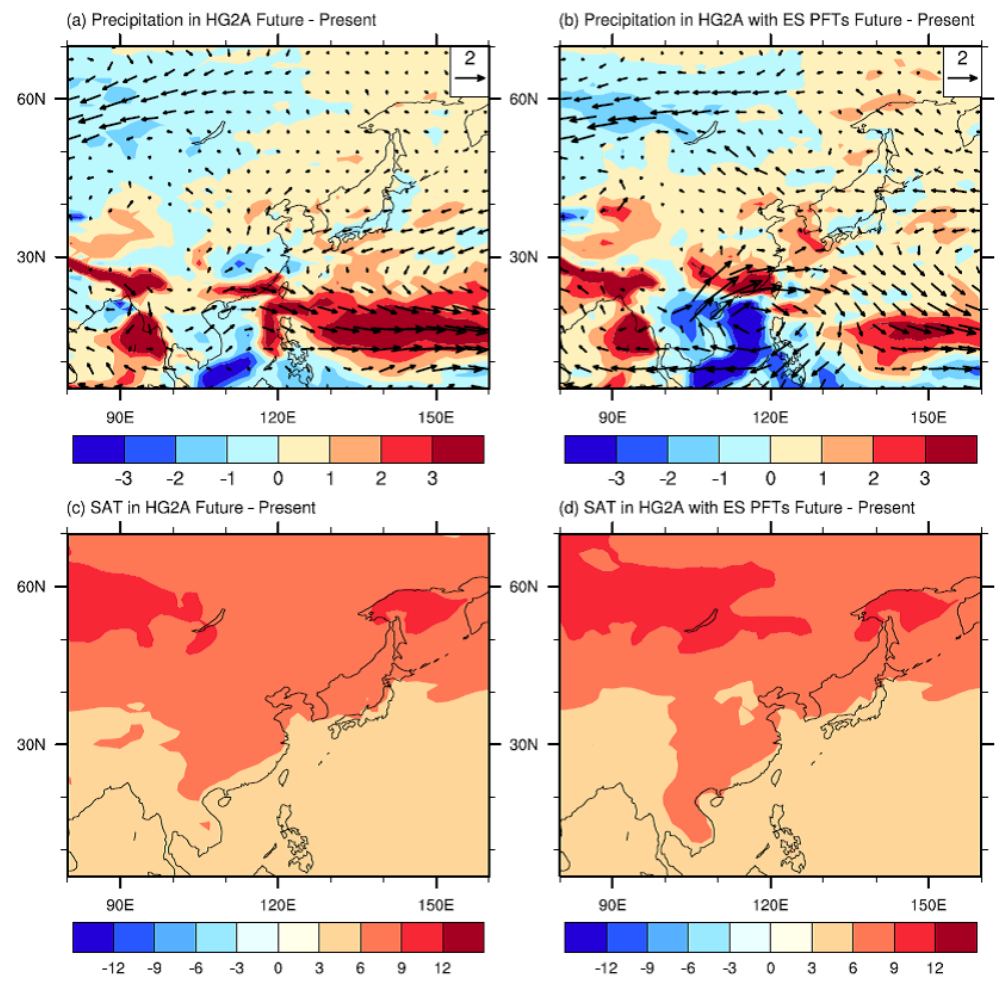

Figure 9. Changes in JJA mean precipitation (shading, $\mathrm{mm} \mathrm{day}^{-1}$ ) between the future time slice and the present-day HadGEM2-A experiments, without $(\mathbf{a}, \mathbf{c})$ and with $(\mathbf{b}, \mathbf{d})$ land cover from HadGEM2-ES. (a), (c) is (Ats-A) and (b), (d) is (AEts-AE).

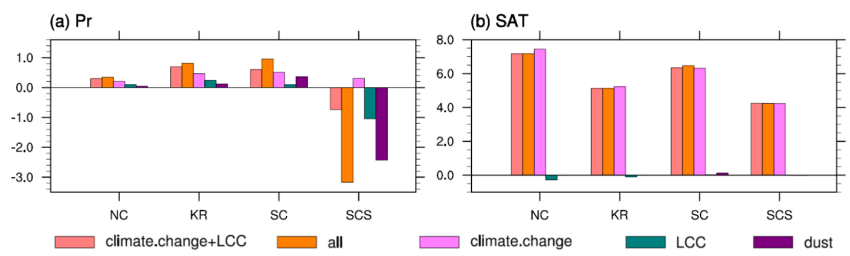

Figure 10. Future changes in precipitation $\left(\mathrm{mm} \mathrm{day}^{-1}\right)(\mathbf{a})$ and surface air temperature $(\mathrm{K})(\mathbf{b})$ over the box regions of North China (NC), Korea (KR), south China (SC) and the South China Sea (SCS) in summer. Note that "all" means sum of climate change, land cover change and direct radiative effect of dust; "LCC" and "Dust" are "double differences", illustrating the influence of those processes on the future-present changes.

rises in the time slice experiments are of a similar magnitude (Figs. 9c, d, 10b). Consistent with this, Figs. 9 and 10 project a warmer and wetter climate in future summers over NC, KR and SC. Figs. 9b and 10a show that a larger increase in rainfall between future and present time slice runs is simulated in these regions when land cover change and feedback on the dust are included. However, while precipitation changes over the SCS region tend to be slightly positive on average in climate-change-only, including land cover changes and feedback with dust induces a reduction in rainfall in this region.
The land surface cover differences in this region between future and present-day climate projected by this model are in $\mathrm{C}_{3}$ grass expansion replacing bare soil (Fig. $11 \mathrm{c}, \mathrm{f}$ ). These changes contribute increases in the evaporation and latent heat flux and decreases in surface air temperature (Fig. 12a, b) to the overall future-present changes. Comparison between (AEnodts-AEnod) and (Ats-A) in Fig. 9 showed that the changes in land cover contribute to increased rainfall over land and reduced rainfall over the SCS. Increasing latent heat flux accompanies lower boundary layer height and is associated with boundary layer moistening (Fig. 12c). According to Lee et al. $(2009,2011)$, a more vegetated surface tends to be associated with surface moistening, favouring an increase in latent heat and atmospheric moisture (Fig. 12). The changes in vegetation and associated changes in surface air temperature, latent heat fluxes (Fig. 12a and b) and low-level circulation (Fig. 12d) show a similar pattern, but the opposite sign, to those shown in Figs. 7c, $\mathrm{h}$ and 8a. This suggests that the future differences between experiments with different land cover (AEnodts-Ats) are small compared with the presentday differences (AEnod-A) such that the double difference (AEnodts-AEnod) - (Ats-A) is dominated by the presentday differences. This is consistent with the findings of ML12.

In Fig. 12d, increased rainfall over the SC region from $25^{\circ} \mathrm{N}$ to $35^{\circ} \mathrm{N}$ is associated with additional anomalous convergence and upward motion over the SC region (see 
(a) Broadleaf tree

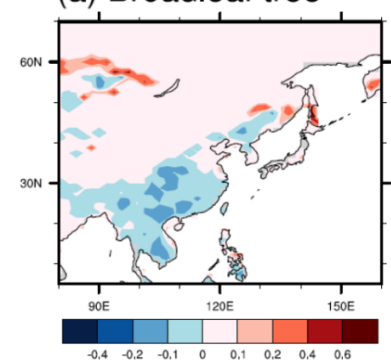

(d) C4 grass

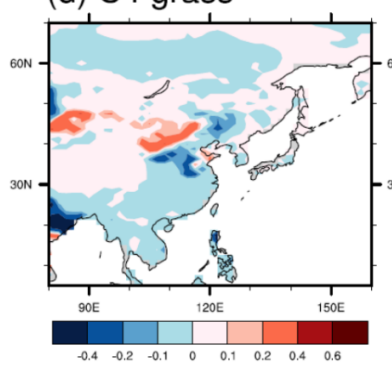

(b) Needleleaf tree

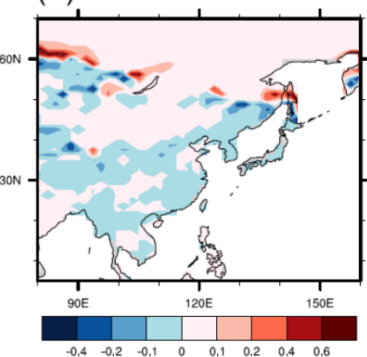

(e) Shrub

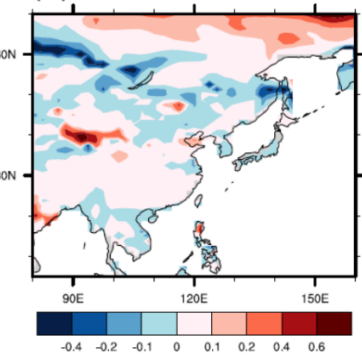

(c) C3 grass

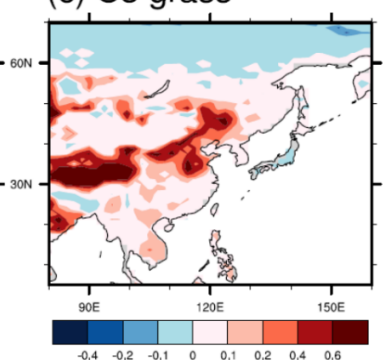

(f) Bare Soil

Figure 11. Changes in fractions in land cover between ca. 2100 and present-day as simulated by HadGEM2-ES in the Fifth Coupled Model Intercomparison Project (CMIP5) Representative Concentration Pathway (RCP) 8.5 scenario and applied in AE present and AEts future time slice experiments.

(a) LHF

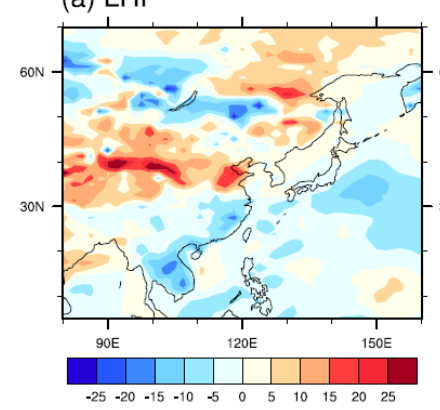

(c) $\mathrm{RH} 1.5 \mathrm{~m}$

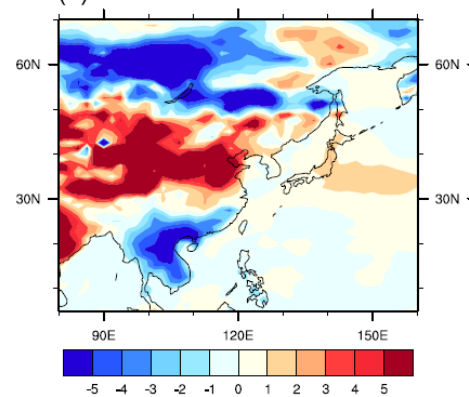

Figure 12. Contribution by the land cover changes alone to the future-present differences in JJA (represented by (AEnodts-AEnod) - (Ats-A) in (a) latent heat flux $\left(\mathrm{W} \mathrm{m}^{-2}\right)$, (b) surface air temperature $(\mathrm{K})$, (c) $1.5 \mathrm{~m}$ relative humidity $(\%)$ and (d) rainfall (shading, $\mathrm{mm} \mathrm{day}^{-1}$ ) and $850 \mathrm{hPa}$ wind (vectors, $\left.\mathrm{ms}^{-1}\right)$. (b) $\mathrm{T} 15$

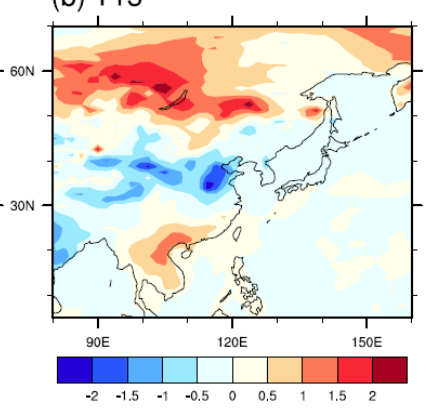

(d) Rainfall and Wind

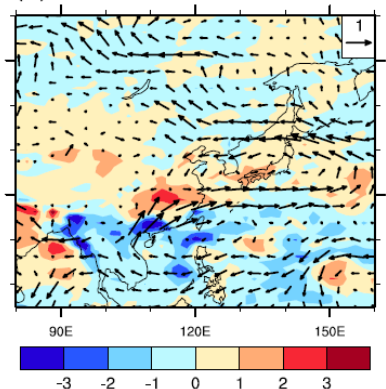

Fig. 13a) induced by the land cover change effect as the monsoon differential circulation results in enhanced moisture transport and cloud formation over SC and KR. In contrast, over the SCS, anomalous anticyclonic flow is related to downward motion from 10 to $20^{\circ} \mathrm{N}$ (Fig. 13a) and reduced rainfall (Fig. 12d). The local influence on rainfall of the changes in surface temperature, fluxes and low-level circulation related to the changes in land cover over east Asia are in contrast to the larger-scale responses described in ML12 for south Asia, where the role of future changes in tree cover over northeast Eurasia in the dynamical response associated with the change in the meridional temperature gradient was highlighted.

As shown in Fig. 10a, the dust radiative forcing is the main contributor to the reduction in simulated precipitation over SCS to the south of $20^{\circ} \mathrm{N}$ in the AEts future experiment. Figure 14 shows the double difference (AEts-AE) minus (AEnodts-AEnod). The atmospheric response shown in Fig. 14 seems to be largely the opposite of that in Fig. 8b, e and $\mathrm{f}$, suggesting that it is dominated by the present-day impacts of dust seen between AE and AEnod. In global warming (i.e. future-present), the bare-soil fraction decreases (Fig. 11f) so the dust emission of HadGEM2-ES decreases in the future relative to the present climate (Fig. 15). As mentioned in Sect. 3.1.3, the direct radiative effect of dust seems to induce stronger flow than that of ES land-cover-only effect. The convective region over $\mathrm{SC}$ in the future experiment Ats (Figs. 9a, 13c) is strengthened in AEts (Fig. 9b), and that over the SCS weakened, through the radiative effects of the 
(a) LCC

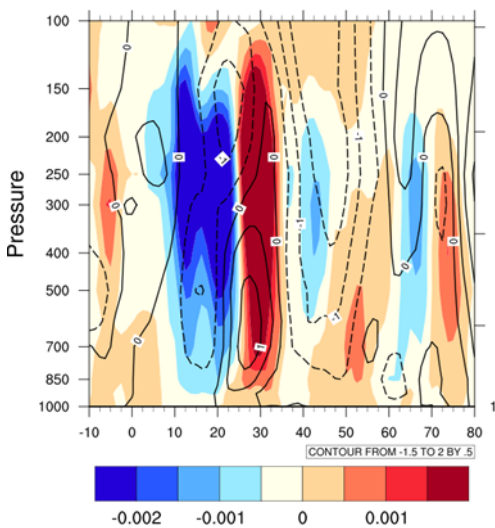

(b) Dust

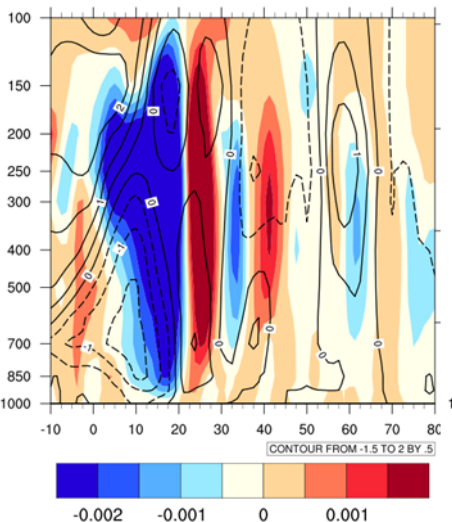

(c) HG2A ts

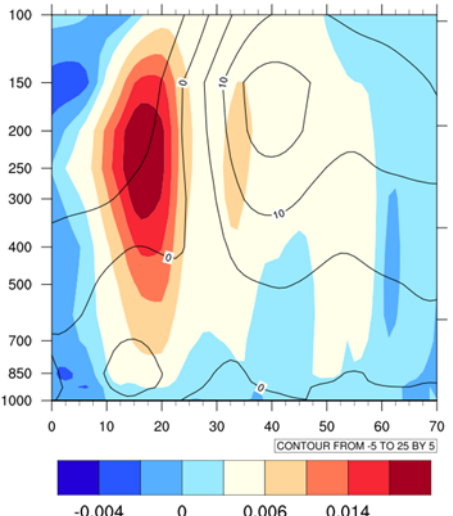

Figure 13. (a and b) Contribution to future-present changes in vertical motion (upward: red; downward: blue) and $U$ wind anomalies (solid line: westerlies) from 110 to $120^{\circ} \mathrm{E}$ driven by (a) LCC impact and (b) dust impact. (c) Climatological vertical motion over $110-120^{\circ} \mathrm{E}$ in the HadGEM2-A time slice run (Ats).

(a) Tsfc

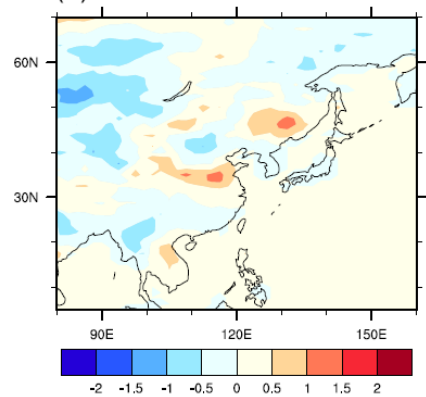

(c) Clear upward SW(TOA)

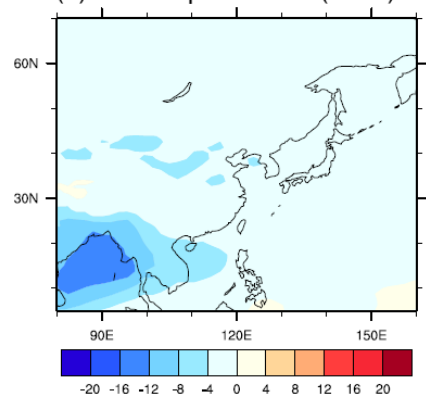

(d) Rainfall and Wind

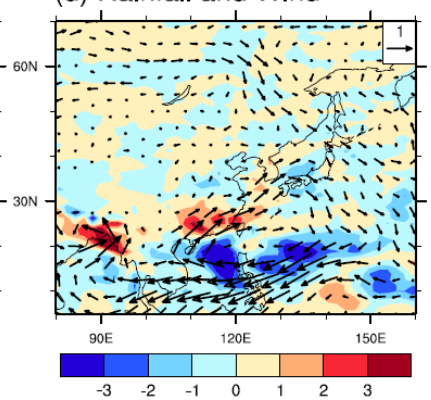

Figure 14. As Fig. 13 but showing the contribution from the direct radiative effect of dust to the future-present differences (represented by (AEts-AE) - (AEnodts-AEnod)) in JJA in (a) surface temperature (K), (b) clear-sky upward longwave radiation at top of atmosphere $\left(\mathrm{W} \mathrm{m}^{-2}\right)$, (c) clear-sky upward shortwave radiation at top of atmosphere $\left(\mathrm{W} \mathrm{m}^{-2}\right)$ and (d) rainfall (shading, mm day ${ }^{-1}$ ) and $850 \mathrm{hPa}$ wind (vectors, $\mathrm{m} \mathrm{s}^{-1}$ ).

reduced dust loading (Fig. 13b), with related increases and decreases in precipitation (Figs. 14d and 10a).

Overall, for future precipitation projection over east Asia using this model, simulating interactive land cover change with a DGVM, and particularly the subsequent changes in

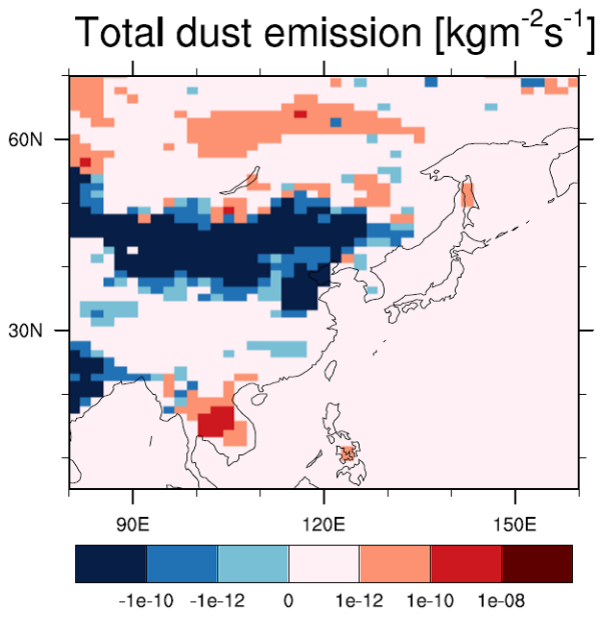

Figure 15. Future changes in total dust emission $\left(\mathrm{kg} \mathrm{m}^{-2} \mathrm{~s}^{-1}\right)$ in JJA from AEts-AE.

dust radiative effect, are at least as important as the warming conditions. In contrast, for future changes in temperature, the global warming effect is dominant among climate change, land cover change and dust radiative effects over east Asia (Figs. 9c, d and 10b).

\section{Summary and Discussion}

In this study, the impact of varying land cover distribution, as simulated with a DGVM, on simulated regional climate over east Asia is examined. The interaction between land cover change by the DGVM and model systematic biases are shown in the present-day climate. The climatology of HadGEM2-A has an underestimation of rainfall over KR in summer and an overestimation over SC. When the land cover from HadGEM2-ES, which uses an interactive vegetation 
model, is used as an input to HadGEM2-A (experiment AE), the precipitation bias is enhanced over KR and SCS. The difference between $\mathrm{AE}$ and $\mathrm{A}$ is related to regional bare-soil expansion by the DGVM through interaction with the rainfall bias, and also through feedback with the subsequent dust loading, causing a direct radiative effect. The direct radiative effect of dust has an important influence on both the precipitation bias and the stronger circulation response in SLP (sea level pressure) and wind than the land-cover-only effect does. In this study, more dust loading due to excessive bare-soil fraction induces an amplified dry bias over Asia. The land cover difference between $\mathrm{AE}$ and $\mathrm{A}$ affects the surface air temperature bias. In summer, a warm bias in NC (Fig. 7h) is due to bare-soil area expansion replacing vegetation (Fig. 7). Soil fraction expands (shrinks) and temperature rises (drops) over NC (SC) (Fig. 7) through changes in surface roughness, evaporation and latent heat fluxes.

The dust loading is expected to reduce in the future time slice run, since $\mathrm{C}_{3}$ grass replaces bare-soil area over NC. The consequent direct radiative effect of dust changes induces the opposite direction of anomalous wind flow over the SCS compared with that induced by the $\mathrm{CO}_{2}$ increase alone. Thus, in the future projection, suppressed rainfall appears over the SCS. Just as the direct radiative effect is significant in the future precipitation simulation, the land cover effect is also important. The $\mathrm{C}_{3}$ grass expansion replacing bare soil, inducing an increase in latent heat flux, lowers the surface temperature. The changes in land cover between future and present day tend to oppose the surface warming over $\mathrm{NC}$ and $\mathrm{KR}$ in summer that are driven by increasing $\mathrm{CO}_{2}$ in the time slice experiments. When the land cover change impacts and associated dust radiative effect are combined, the resulting rainfall under future climate differs regionally. In contrast with the precipitation response, the temperature response in the time slice run is dominated by the warming induced from the atmospheric $\mathrm{CO}_{2}$ increase. In terms of the projected temperature rise, the ES land cover and dust radiative effects are very small. Overall, the inclusion of land cover changes as simulated by an interactive vegetation model has impacts on both present and future climate in east Asia. These results are similar to those for India shown in ML12, although the response amplitude is different. In addition, local rather than remote mechanisms appear to influence the precipitation and circulation response in this region, whereas for India the role of land cover changes in northern Eurasia on the large-scale meridional temperature gradient was highlighted in ML12.

The inclusion of dynamic vegetation components in a climate model allows impacts of climate change on both atmospheric composition and ecosystems. When the various feedbacks among the model components are included, complexity increases and the feedbacks affect more numerous systematic biases in models and future climate projections (ML12). As discussed in ML12, as additional earth system processes are included in a model, the complex interactions and feedbacks between these additional parameterized pro- cesses and the model's existing systematic biases, e.g. in rainfall, can be an additional source of uncertainty in climate projection. Therefore, it is imperative that model developers continue to strive to improve physical parameterizations in modelling systems. We would emphasize that the details of our results may be dependent on the particular modelling system used for this study. Experiments with more subtle or realistically possible land cover changes have not been carried out for this region with this model, and studies of the influence of vegetation changes using other models (e.g. Lee et al., 2011) have not examined the feedbacks on dust. Therefore, we are unable to speculate on the relative importance of the dust feedback effects under more subtle or realistically possible land cover change scenarios. Nevertheless, our results suggest that vegetation feedbacks may be important over east Asia, particularly in the dust emission source regions, for present-day and future climate simulation. Thus, we encourage other modelling centres to investigate these responses in other models, where the biases may be different.

Acknowledgements. This research was supported by the National Institute of Meteorological Research, Korea Meteorological Administration (project NIMR-2012-B-2), and it used the Unified Model (UM) licence. G. M. Martin was supported by the Joint UK DECC/Defra Met Office Hadley Centre Climate Programme (GA01101) and by the NERC Changing Water Cycle (South Asia) project SAPRISE, grant number NE/I022469/1.

Edited by: A. Kleidon

\section{References}

Adler, R. F., Huffman, G. J., Chang, A., Ferraro, R., Xie, P., Janowiak, J., Rudolf, B., Schneider, U., Curtis, S., Bolvin, D., Gruber, A., Susskind, J., Arkin, P., and Nelkin, E.: The Version 2 Global Precipitation Climatology Project (GPCP) Monthly Precipitation Analysis (1979-Present), J. Hydrometeor., 4, 11471167, 2003.

Baek, H.-J., Lee, J., Lee, H.-S., Cho, C., Kwon, W.-T., Marzin, C., Hyun, Y.-K., Gan,S.-Y., Kim, M.-J., Choi, D.-H., Lee, J., Lee, J., Boo, K.-O., Kang, H.-S., and Byun, Y.-H.: Climate change in the 21st century simulated by HadGEM2-AO under Representative Concentration Pathways, Asia-Pac. J. Atmos. Sci., 49, 603-618, 2013.

Batlle Bayer, L., van den Hurk, B. J. J. M., Strengers, B. J., and van Minnen, J. G.: Regional feedbacks under changing climate and land-use conditions, Earth Syst. Dynam. Discuss., 3, 201-234, doi:10.5194/esdd-3-201-2012, 2012.

Cox, P. M.: Description of the "TRIFFID" Dynamic Global Vegetation Model, Hadley Centre Technical Note No. 24, available at: http://www.metoffice.gov.uk/media/pdf/9/h/HCTN_24. pdf (last access: 20 July 2012), Met Office Hadley Centre, Exeter, UK, 2001.

Cox, P. M., Betts, R. A., Bunton, C. B., Essery, R. L. H., Rowntree, P. R., and Smith, J.: The impact of new land surface physics 
on the GCM simulation of climate and climate sensitivity, Clim. Dynam., 15, 3, 183-203, doi:10.1007/s003820050276, 1999.

Collins, W. J., Bellouin, N., Doutriaux-Boucher, M., Gedney, N., Halloran, P., Hinton, T., Hughes, J., Jones, C. D., Joshi, M., Liddicoat, S., Martin, G., O’Connor, F., Rae, J., Senior, C., Sitch, S., Totterdell, I., Wiltshire, A., and Woodward, S.: Development and evaluation of an Earth-System model - HadGEM2, Geosci. Model Dev., 4, 1051-1075, doi:10.5194/gmd-4-10512011, 2011.

Douglas, E. M., Niyogi, D., Frolking, S., Yeluripati, J. B., Pielke Sr., R. A., Niyogi, N., Vorosmarty, C. J., and Mohanty, U. C.: Changes in moisture and energy fluxes due to agricultural land use and irrigation in the Indian Monsoon Belt, Geophys. Res. Lett., 33, L14403, doi:10.1029/2006GL026550, 2006.

Essery, R. and Clark, D. B.: Developments in the MOSES 2 landsurface model for PILPS 2e, Global Planet. Change, 38, 161164, doi:10.1016/j.bbr.2011.03.031, 2003.

Harris, I., Jones, P. D., Osborn, T. J., and Lister, D. H.: Updated high-resolution grids of monthly climatic observations - the CRU TS3.10 Dataset, Int. J. Climatol., 34, 623-642, doi:10.1002/joc.3711, 2013.

Huffman, G. J, Adler, R. F., Bolvin, D. T., and Gu, G.: Improving the Global Precipitation Record: GPCP Version 2.1, Geophys. Res. Lett., 36, L17808, doi:10.1029/2009GL040000, 2009.

Hurrell, J., Meehl, G. A., Bader, D., Delworth, T. L., Kirtman, B., and Wielicki, B.: A unified modeling approach to climate system prediction, B. Am. Meteorol. Soc., 90, 1819-1832, doi:10.1175/2009BAMS2752.1, 2009.

Hurtt, G. C., Chini, L. P., Frolking, S., Betts, R., Feddema, J., Fischer,G., Fisk, J. P., Hibbard, K., Houghton, R. A., Janetos, A.,Jones, C., Kindermann, G., Kinoshita, T., Klein Goldewijk, K.,Riahi, K., Shevliakova, E., Smith, S., Stehfest, E., Thomson, A., Thornton, P., van Vuuren, D. P., and Wang, Y.: Harmonization of Land-Use Scenarios for the Period 1500-2100: 600 Years of Global Gridded Annual Land-Use Transitions, Wood Harvest, and Resulting Secondary Lands, Climatic Change, 109, 117161, doi:10.1007/s10584-011-0153-2, 2011.

Jones, C. D., Hughes, J. K., Bellouin, N., Hardiman, S. C., Jones, G. S., Knight, J., Liddicoat, S., O'Connor, F. M., Andres, R. J., Bell, C., Boo, K.-O., Bozzo, A., Butchart, N., Cadule, P., Corbin, K. D., Doutriaux-Boucher, M., Friedlingstein, P., Gornall, J., Gray, L., Halloran, P. R., Hurtt, G., Ingram, W. J., Lamarque, J.-F., Law, R. M., Meinshausen, M., Osprey, S., Palin, E. J., Parsons Chini, L., Raddatz, T., Sanderson, M. G., Sellar, A. A., Schurer, A., Valdes, P., Wood, N., Woodward, S., Yoshioka, M., and Zerroukat, M.: The HadGEM2-ES implementation of CMIP5 centennial simulations, Geosci. Model Dev., 4, 543-570, doi:10.5194/gmd-4-543-2011, 2011.

Kang, H.-S. and Hong, S.-Y.: An assessment of the land surface parameters on the simulated regional climate circulations: The 1997 and 1998 east Asian summer monsoon cases, J. Geophys. Res., 113, D15121, doi:10.1029/2007D009499, 2008.

Kang, H.-S., Cha, D.-H., and Lee, D.-K.: Evaluation of the mesoscale model/land surface model (MM5/LSM) coupled model for East Asian summer monsoon simulations, J. Geophys. Res., 110, D10105, doi:10.1029/2004JD005266, 2005.

Konaré, A., Zakey, A. S., Solmon, F., Giorgi, F., Rauscher, S., Ibrah, S., and Bi, X.: A regional climate modeling study of the effect of desert dust on the West African monsoon, J. Geophys. Res., 113, D12206, doi:10.1029/2007JD009322, 2008.

Lau, K. M. and Li, M.-T.: The monsoon of East Asia and its global associations-A survey, B. Am. Meteorol. Soc., 65, 114 125,1984

Lau, K. M and Kim ,K.-M.: Observational relationships between aerosol and Asian monsoon rainfall, and circulation, Geophys. Res. Lett., 33, L21810, doi:10.1029/2006GL027546, 2006.

Lau, K. M., Kim, M. K., and Kim, K. M.: Asian monsoon anomalies induced by aerosol direct effects, Clim. Dyn., 26, 855-864, doi:10.1007/s00382-006-0114-z, 2006.

Lawrence. D. M. and Slingo, J. M.: An annual cycle of vegetation in a GCM. Part I: implementation and impact on evaporation, Clim. Dynam., 22, 87-105, doi:10.1007/s00382-003-0366-9, 2004.

Lee, E., Chase, T. N., Rajagopalan, B., Barry, R. G., Biggs, T. W., and Lawrence, P. J.: Effects of irrigation and vegetation activity on early Indian summer and monsoon variability, Int. J. Climatol., 29, 573-581, doi:10.1002/joc.1721, 2009.

Lee, E., Barford, C. C., Kucharik, C. J., Felzer, B. S., and Foley, J. A.: Role of turbulent heat fluxes over land in the monsoon over East Asia, Int. J. Geosci., 2, 420-431, doi:10.4236/ijg.2011.24046, 2011.

Lee, E. J., Yeh, S. W., Jhun, J. G., and Moon, B. K.: Seasonal change in anomalous WNPSH associated with the strong East Asian summer monsoon, Geo. Res. Let., 33, L21702, doi:10.1029/2006GL027474, 2006.

Loveland, T. R., Reed, B. C., Brown, J. F., Ohlen, D. O., Zhu, Z., Yang, L., and Merchant, J. W.: Development of a global land cover characteristics database and IGBP DISCover from $1 \mathrm{~km}$ AVHRR data, Int. J. Remote Sensing, 21, 1303-1330, doi:10.1080/014311600210191, 2000.

Martin, G. M. and Levine, R. C.: The influence of dynamic vegetation on the present-day simulation and future projections of the South Asian summer monsoon in the HadGEM2 family, Earth Syst. Dynam., 3, 245-261, doi:10.5194/esd-3-245-2012, 2012.

McCarthy, M. P., Sanjay, J., Booth, B. B. B., Krishna Kumar, K., and Betts, R. A.: The influence of vegetation on the ITCZ and South Asian monsoon in HadCM3, Earth Syst. Dynam., 3, 8796, doi:10.5194/esd-3-87-2012, 2012.

Miller, R. L. and Tegen, I.: Climate response to soil dust aerosols, J. Clim., 11, 3247-3267, 1998.

Paeth, H. and Feichter, J.: Greenhouse-gas versus aerosol forcingand African climate response, Clim. Dyn., 26, 35-54, 2005.

Qian, Y., Gong, D., Fan, J., Leung, L. R., Bennartz, R., Chen, D., and Wang ,W.: Heavy pollution suppresses light rain in China: Observations and modeling, J. Geophys. Res., 114, D00K02, doi:10.1029/2008JD011575, 2009.

Ramanathan, V., Chung, C., Kim, D., Betge, T., Buja, L., Kiehl, J. T., Washington, W. M., Fu, Q., Sikka, D. R., and Wild, M.: Atmospheric brown clouds: Impacts on South Asian climate and hydrological cycle, P. Natl. Acad. Sci. USA, 102, 5326-5333, doi:10.1073/pnas.0500656102, 2005.

Sokolik, I. N. and Toon, O. B.: Direct radiative forcing by anthropogenic airborne mineral aerosols, Nature, 381, 681-683, 1996.

Suh, M.-S. and Lee, D.-K. : Impacts of land use/cover changes on surface climate over east Asia for extreme climate cases using RegCM2, J. Geophys. Res., 109, D02108, doi:10.1029/2003JD003681, 2004. 
Taylor, K. E., Stouffer, R. J., and Meehl, G. A: An Overview of CMIP5 and the experiment design, B. Am. Meteorol. Soc., 93, 485-498, doi:10.1175/BAMS-D-11-00094.1, 2012.

The HadGEM2 Development Team: G. M. Martin, Bellouin, N., Collins, W. J., Culverwell, I. D., Halloran, P. R., Hardiman, S. C., Hinton, T. J., Jones, C. D., McDonald, R. E., McLaren, A. J., O'Connor, F. M., Roberts, M. J., Rodriguez, J. M., Woodward, S., Best, M. J., Brooks, M. E., Brown, A. R., Butchart, N., Dearden, C., Derbyshire, S. H., Dharssi, I., Doutriaux-Boucher, M., Edwards, J. M., Falloon, P. D., Gedney, N., Gray, L. J., Hewitt, H. T., Hobson, M., Huddleston, M. R., Hughes, J., Ineson, S., Ingram, W. J., James, P. M., Johns, T. C., Johnson, C. E., Jones, A., Jones, C. P., Joshi, M. M., Keen, A. B., Liddicoat, S., Lock, A. P., Maidens, A. V., Manners, J. C., Milton, S. F., Rae, J. G. L., Ridley, J. K., Sellar, A., Senior, C. A., Totterdell, I. J., Verhoef, A., Vidale, P. L., and Wiltshire, A.: The HadGEM2 family of Met Office Unified Model climate configurations, Geosci. Model Dev., 4, 723-757, doi:10.5194/gmd-4-723-2011, 2011.

Webster, P. J., Magana, V. O., Palmer, T. N., Shukla, J., Tomas, R. A., Yanai, M., and Yasunari T.: Monsoons: Processes, Predictability, and the Prospects for Prediction, Journal of Geophysical Research, 3, 14451-14510. doi:10.1029/97JC02719, 1998.
Woodward, S.: Mineral dust in HadGEM2. Hadley Centre Technical Note 87, Met Office Hadley Centre., Exeter, EX1 3PB, UK, available at: http://www.metoffice.gov.uk/learning/library/ publications/science/climate-science-technical-notes (last access: 18 December 2014), 2011.

Xie, P. and Arkin, P. A.: Global precipitation: A 17-year monthly analysis based on gauge observations, satellite estimates, and numerical model outputs. Bull. Amer. Meteor. Soc., 78, 2539-2558, 1997.

Yamashima, R., Takata, K., Matsumoto, J., and Yasunari, T.: Numerical study of the impacts of land use/cover changes between 1700 and 1850 on the seasonal hydroclimate in monsoon Asia, J. Meteorol. Soc. Japan, 89A, 291-298, doi:10.2151/jmsj.2011A19, 2011.

Yoshioka, M., Mahowald, N. M., Conley, A. J., Collins, W. D., Fillmore, D. W., Zender, C. S., and Coleman, D. B.: Impact of desert dust radiative forcing on Sahel precipitation: relative importance of dust compared to sea surface temperature variations, vegetation changes, and greenhouse gas warming, J. Clim., 20, 14451467, doi:10.1175/JCLI4056.1, 2007. 